\title{
食肉処理場で採取した卵巣を用いた牛体外受精胚作出過程での 細菌分離と細菌污染が体外受精胚の発生能に及ぼす影響
}

\author{
内布 幸典・増岡 和晃 ${ }^{1)}$-堤 尚三1) \\ 小森 敏宏 11 ・音井 威重 21
}

\author{
福岡県中央家畜保健衛生所 7816 福岡市博多区井相田2-1-3 \\ 1) 福岡県北九州家畜保健衛生所 $\bar{\top}$ 800-02 北九州市小倉南区中吉田3-20-13 \\ 2) 徳島県肉畜試験場 7774 徳島県阿南市下大野町渡り上り
}

\begin{abstract}
要 約 牛体外受精胚の作出過程で用いた卵巣輸送用の生理食塩液, 卵巣洗浄液, 卵子吸引液, 成熟培養液, 媒 精後 2 日目および 8 日目の発生培養液にペニシリン（PC）+ストレプトマイシン（SM）を添加した区並びに無 添加の区を設け，それぞれについて細菌の分離および分離菌株の薬剤感受性の検討を行い，併せて体外受精胚の 卵割率と胚盤胞への発生率を比較した。P C + S M 添加区の卵巣輸送液および卵巣洗浄液からは，10 ${ }^{1} \sim 10^{3}$ Colony Forming Units (CFU) / $\mathrm{ml}$ の細菌が分離されたが, それ以降の卵子吸引液および各培責液からは分離され なかった。一方, 無添加区においては, 発生培養液を含む全供試材料から, $10^{1} \sim 10^{6} \mathrm{CFU} / \mathrm{ml}$ の細菌が分離さ れた. また、卵巣輸送液から分離された細菌は，グラム陰性桿菌が主体を占め，その中でも腸内細菌が優勢で, 分離菌株の多くは，ペニシリン系，マクロライド系，テトラサイクリン系，セフェム系に耐性を示した．PC十 S M 添加区の体外受精胚の卵割率および発生率は，抗生物質無添加区に比べ有意に高い值を示した $(\mathrm{P}<0.01)$. 以上から, 体外受精胚作出過程におけるP C + S M の添加は, 細菌の除去並びに胚の発生に有効であることが示 されたが，PCおよびSMに対し耐性を示す細菌が分離されたことから，胚による病原細菌の伝播を防御するた めには抗菌範囲の広い抗生物質の選択が必要であることが示唆された.

キーワード : Antibiotics, Bacteria, Bovine oocyte, In vitro development.
\end{abstract}

(Journal of Reproduction and Development, 42 : j1-j6, 1996)

近年, 牛体外受精技術は, 肉用肥育素牛を経済的, かつ効率的に増産できることから，国内において積極 的な取り組みがなされている。一方，本技術は屠畜牛 由来の卵巣を利用することから，卵子の処理および肧 の発生過程に扔いて病原微生物感染の危険にさらされ ている。体内受精胚に扔いては, 細菌もしくはウイル スの肧に対する付着能または洗浄による清浄化を検討 した研究 $[1-4]$ が多くなされてきたが，牛の体外 受精胚についての報告は少ない。 そこで本研究では,

揭載採用：1995年 11 月 2 日
牛体外受精胚の作出過程における細菌污染の実態を確 認するため，卵巣輸送に用いた生理食塩液，卵子採取 後から胚発生までに用いた修正リン酸緩衝液および培 養液から細菌の分離を試み，分離した菌株の薬剤感受 性を検討した。

また, 体外培養過程での細菌污染が受精胚の卵割率, 胚盤胞への発生率に及ぼす影響についても検討した。

\section{材料と方法}

\section{体外受精胚の作出}

北九州市立食肉センターで屠殺されたホルスタイン 
種および黒毛和種の卵巣を, 内臟検査台上で切り取り, $30 \sim 33{ }^{\circ} \mathrm{C}$ に保温した滅菌生理食塩液 (卵巣輸送液) に 浸し，1 時間の行程で実験室まで輸送した。実験室に到 着後, 新しい滅菌生理食塩液 (2L ; 卵巣洗浄液) で卵 巣をもみ洗いし，この間洗浄液交換を 5 回行った。次い で卵巣表面を滅菌紙夕オルで清拭し, $0.3 \%$ 牛血清アル ブミン加修正りん酸䋧衝液（mPBS）を約 $1 \mathrm{ml}$ 吸った $18 \mathrm{G}$ の注射針の付いた $5 \mathrm{ml}$ 滅菌シリンジを用いて卵巣 から卵子を吸引した。採取した卵子は mPBS および $5 \%$ 子牛血清（CS）を添加した 25 mM HEPES 緩衝 TCM-199 (成熟培養液) でそれぞれ 2 回洗浄し, 成熟培養に供し た。体外成熟, 媒精および培養は, 梶原ら［5]の方法 に準じて行った。なお，体外受精に使用した精液は家畜 改良事業団所有の熱富士を用いた。

媒精後, 成熟培養に供した 4 穴シャーレを用いて発生 培養を行った。発生培養液は, 25 mM HEPES 緩衝TCM199 に 10 \% CS を添加した液とした。媒精 48 時間後に発 生培養液の交換および胚の裸化を行い, 体外受精胚の卵 割率を検査した。培養は媒精日を0日として8日目まで 行い, 媒精後 8 日目に、初期胚盤胞から脱出胚盤胞に発 育した数を記録した。なお，卵割率および発生率の有意 差検定は $\chi^{2}$ 検定で行った。

抗生物質添加の有無による分離細菌の数と種類および 胚の発生率を比較するために, 卵巣輸送液, 卵巣洗浄液, 卵子吸引液, 成熟培養液, 精子処理液および発生培養液 にペニシリン（PC；100IU/ml）＋ストレプトマイシン $(\mathrm{SM} ; 100 \mu \mathrm{g} / \mathrm{ml})$ （以下, PC＋SM）を添加した区と 無添加区の 2 群を設けた。

\section{細菌検査}

\section{1) 供試材料}

卵巣輸送液および輸送後, 滅菌生理食塩液で 5 回液を 交換した最終の卵巣洗浄液, 卵巣から卵胞液を吸引し試 験管に移動後の mPBS を含む上澄み液 (卵子吸引液), 卵子を採取後 $20 \sim 24$ 時間培養した成熟培養液，媒精後 2 日目および 8 日目の発生培養液について細菌の分離を 試みた。

\section{2 ）細菌の分離}

供試材料を $5 \%$ 馬血液加トリプトソイ寒天培地, デス オキシコーレイト寒天培地, 卵黄加マンニット食塩寒天 培地, ハートインヒュージョンブイヨンを用い $39 \mathrm{C}$, $5 \% \mathrm{CO}_{2}, 95 \%$ 空気の条件下, $24 \sim 48$ 時間培養を行っ た．細菌数は， 3 枚の $5 \%$ 馬血液加トリプトソイ寒天培 地上に現われたコロニー数を計測し，その平均を求めた。
なお卵巣輸送液からの分離菌について，グラム染色によ

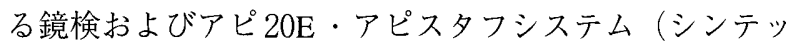
ク社）により生化学的性状の同定を行った [6].

\section{3 ) 薬剤感受性試験}

抗生物質添加区および無添加区の卵巣輸送液からの分離 菌のうち、Escherichia coli (E.coli) 10 株, Enterobacter cloacae (Ent.cloacae) 8株, Proteus vulgaris 4 株, Salmonella spp. 4 株, Pseudomonas aeruginosa (Ps.aeruginosa) 5 株, Acinetobacter spp. 4 株, Staphylococcus capitis (St.capitis) 6 株, Staphylococcus epidermidis (St.epidermidis) 3 株, Staphylococcus aureus (St.aureus) 2 株の計 46 株について, ベンジルペニシリンカリウム (PCG), クロキサシリンナトリウム $(\mathrm{MCIPC})$, ジクロ キサシリンナトリウム (MDIPC)，アンピシリン $(\mathrm{ABPC})$, アモキシシリン (AMPC), メシリナム (PMPC), 硫酸ストレプトマイシン $(\mathrm{SM})$, 硫酸カナマ イシン $(\mathrm{KM})$, 硫酸フラジオマイシン $(\mathrm{FRM})$, 硫酸ゲ ンタマイシン $(\mathrm{GM})$, エリスロマイシン $(\mathrm{EM})$, オレ アンドマイシン $(\mathrm{OL})$, スピラマイシン $(\mathrm{SPM})$, 塩酸 テトラサイクリン (TC), 塩酸オキシテトラサイクリン (OTC)，セファゾリン (CEZ)，セフロキシムナトリウ 厶 $(\mathrm{CXM})$, チアンフェニコール $(\mathrm{T} \mathrm{p})$, コリスチン (CL) の薬剤に対する感受性を感受性ディスク用培地一 N（ニッスイ）を用い感受性ディスク（昭和）により実 施した。感受性は昭和ディスクユーザーズマニュ アルによりー〜+++の 4 段階に区分し, +十以上を感 受性を有する菌株と判定した。

\section{結果}

\section{細菌分離}

$\mathrm{PC}+\mathrm{SM}$ 添加区においては, 卵巣輸送液から $1.8 \times$ $10^{2} \sim 8.5 \times 10^{3}$ Colony Forming Units $(\mathrm{CFU} / \mathrm{ml})$ の範囲で, また卵巣洗浄液からは, $1.0 \times 10^{1} \sim 1.3 \times 10^{2} \mathrm{CFU} / \mathrm{ml}$ の 範囲で細菌が分離された。 しかし, 卵子吸引液, 成熟培 養液, 発生培養液からは細菌が検出されなかった。一方, 抗生物質無添加区において卵巣輸送液から, $6.4 \times 10^{3}$ $8.5 \times 10^{4} \mathrm{CFU} / \mathrm{ml}$ の範囲で, また卵巣洗浄液から, $1.1 \times$ $10^{2} \sim 3.5 \times 10^{3} \mathrm{CFU} / \mathrm{ml}$ の範囲で細菌が分離された。そ れ以降の卵子吸引液および成熟培養液からも細菌が分離 され, 媒精後 8 日目の発生培養液からは, $3.7 \times 10^{3} \sim$ $2.6 \times 10^{6} \mathrm{CFU} / \mathrm{ml}$ の範囲で細菌が分離された（表 1 ）。

\section{分離細菌の性状}

グラム院性桿菌が主体を占め, その中でも特に腸内細 菌類が全体の $52.8 \%$ と優勢であった。また PC+SM 添 
加区からグラム陽性菌は分離されなかった（表 2)，

\section{分離細菌の薬剤感受性}

ペニシリン系では, 46株中 ABPC：18株，AMPC：19 株およびPMPC：22 株に感受性の低下が認められた。マ クロライド系では, EM：27株, OL：34 株および SPM：33株が，テトラサイクリン系では，TC：15株お よびOTC：15株が，またセフェム系では，CEZ：25株
およびCXM：19株に感受性の低下が認められた。その 他の抗生物質においても，TP：32株およびCL：26株に 感受性の低下が認められた。一方，アミノグリコシド系 では, 感受性の低下は, SM $: 15$ 株, KM $: 8$ 株, FRM $: 9$ 株および GM：3株に認められた。特に GMは 46 株中 43 株（93.5％）に薬剤感受性を有していた（図 1$)$.

表 1。牛の体外受精胚作出過程における細菌分離

\begin{tabular}{|c|c|c|c|c|c|c|c|}
\hline \multirow{2}{*}{ 処理区 } & & \multirow{2}{*}{ 卵巣輸送液 } & \multirow{2}{*}{ 卵巣洗浄液 } & \multirow{2}{*}{ 卵子吸引液 } & \multirow{2}{*}{ 成熟培養液 } & \multicolumn{2}{|c|}{ 発生培養液 (媒精後) } \\
\hline & & & & & & 2 日目 & 8 日目 \\
\hline \multirow{4}{*}{$\begin{array}{c}\mathrm{PC}+\mathrm{SM} \\
\text { 添加区 }\end{array}$} & (1) & $8.5 \times 10^{3 *}$ & $1.3 \times 10^{2}$ & ND $* *$ & ND & ND & ND \\
\hline & (2) & $3.9 \times 10^{2}$ & $2.0 \times 10^{1}$ & ND & ND & ND & ND \\
\hline & (3) & $2.1 \times 10^{2}$ & $3.0 \times 10^{1}$ & ND & ND & ND & ND \\
\hline & (4) & $1.8 \times 10^{2}$ & $1.0 \times 10^{1}$ & ND & ND & ND & ND \\
\hline \multirow{4}{*}{$\begin{array}{l}\text { 抗生物質 } \\
\text { 無添加区 }\end{array}$} & (1) & $8.5 \times 10^{4}$ & $3.5 \times 10^{3}$ & $2.7 \times 10^{2}$ & $6.4 \times 10^{5}$ & $3.7 \times 10^{6}$ & $2.6 \times 10^{6}$ \\
\hline & (2) & $9.2 \times 10^{3}$ & $2.3 \times 10^{2}$ & $9.0 \times 10^{1}$ & $7.6 \times 10^{3}$ & $2.7 \times 10^{3}$ & $4.9 \times 10^{4}$ \\
\hline & (3) & $7.8 \times 10^{3}$ & $1.1 \times 10^{2}$ & $4.0 \times 10^{1}$ & $6.1 \times 10^{3}$ & $3.1 \times 10^{3}$ & $4.8 \times 10^{4}$ \\
\hline & (4) & $6.4 \times 10^{3}$ & $1.7 \times 10^{2}$ & $3.0 \times 10^{1}$ & $1.0 \times 10^{1}$ & $8.2 \times 10^{2}$ & $3.7 \times 10^{3}$ \\
\hline
\end{tabular}

${ }^{*} \mathrm{CFU} \mathrm{ml}$

${ }^{* *} \mathrm{ND}$; 菌分離除性

表 2、卵巣輸送液から分離した細菌の種類

\begin{tabular}{|c|c|c|c|}
\hline \multirow{2}{*}{ 菌 } & \multicolumn{3}{|c|}{ 株 数 $\quad(\%)$} \\
\hline & 計 & P C + S M 添加区 & 抗生物質無添加区 \\
\hline 腸内細菌科に属するグラム陰性棹菌 & $28 \quad(52.8)$ & $8 \quad(61.5)$ & $20 \quad(50.0)$ \\
\hline Escherichia coli & 10 & 3 & 7 \\
\hline Enterobacter cloacae & 8 & 3 & 5 \\
\hline Proteus vulgaris & 4 & & 4 \\
\hline Salmonella spp. & 4 & 2 & 2 \\
\hline Escherichia fergusonii & 1 & & 1 \\
\hline Enterobacter agglomerans & 1 & & 1 \\
\hline グラム陰性桿菌 & $10(18.9)$ & $5 \quad(38.5)$ & $5 \quad(12.5)$ \\
\hline Pseudomonas aeruginosa & 5 & 3 & 2 \\
\hline Acinetobacter spp. & 4 & 1 & 3 \\
\hline Kluyvera spp. & 1 & 1 & \\
\hline グラム陽性球菌 & $15 \quad(28.3)$ & $0 \quad(0.0)$ & $15 \quad(37.5)$ \\
\hline Staphylococcus capitis & 6 & & 6 \\
\hline Staphylococcus epidermidis & 3 & & 3 \\
\hline Staphylococcus aureus & 2 & & 2 \\
\hline Staphylococcus lentus & 2 & & 2 \\
\hline Staphylococcus sciuri & 1 & & 1 \\
\hline Staphylococcus cohnii & 1 & & 1 \\
\hline 計 & 53 & 13 & 40 \\
\hline
\end{tabular}




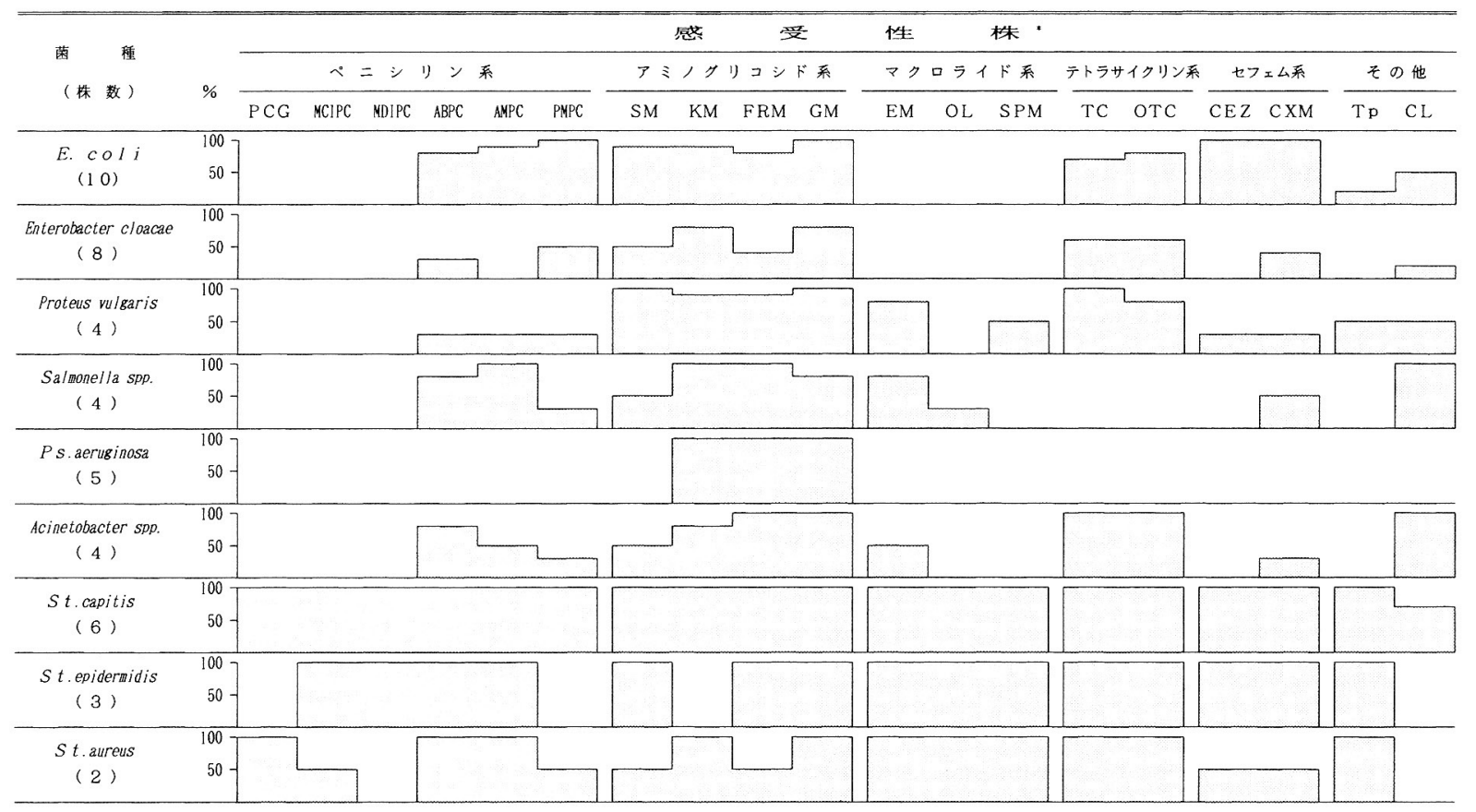

図 1 . 分離細菌の薬椷感受性

*感受性は昭和ディスク 1濃度法による十+以上とした。

PCG：ベンジルペニシリン MCIPC：クロキサシリン MDIPC：ジクロキサシリン ABPC：アンピシリン AMPC：アモキシシリン PMPC：メシリナム SM：ストレプトマイシン KM：カナマイシン

FRM : フラジオマイシン GM : ゲンタマイシン EM：エリスロマイシン OL ：オレアンドマイシン SPM：スピラマイシン TC：テトラサイクリン OTC：オキシテトラサイクリン CEZ：セファゾリン CXM：セフロキシム $\mathrm{Tp}$ ：チアンフェニコール CL：コリスチン

表 3 。体外培養系に㧈ける細菌污染が体外受精後の肧の発生能に及ぼす影響

\begin{tabular}{|c|c|c|c|c|c|c|c|}
\hline & & 供試卵数 & $\begin{array}{l}\text { 舱割率 } \\
\% \quad \text { (数) }\end{array}$ & $\begin{array}{l}\text { 細菌 } \\
\text { 分離* }\end{array}$ & $\begin{array}{c}\text { 胚盤胞 } \\
\% \\
\%\end{array}$ & $\begin{array}{l}\text { 発生率 } \\
\text { (数) }\end{array}$ & $\begin{array}{l}\text { 細菌 } \\
\text { 分離* }\end{array}$ \\
\hline \multirow{5}{*}{$\begin{array}{c}\mathrm{PC}+\mathrm{SM} \\
\text { 添加区 }\end{array}$} & (1) & 99 & $41.4(41)$ & $\mathrm{ND}^{* *}$ & 6.1 & $(6)$ & ND \\
\hline & $(2)$ & 78 & $48.7(38)$ & ND & 14.1 & (11) & ND \\
\hline & (3) & 75 & $45.3(34)$ & ND & 10.7 & ( 8$)$ & ND \\
\hline & (4) & 95 & $51.6(49)$ & ND & 9.5 & ( 9$)$ & ND \\
\hline & 計 & 347 & $46.7(162)^{\mathrm{a}}$ & ND & 9.8 & $(34)^{a}$ & \\
\hline \multirow{5}{*}{$\begin{array}{l}\text { 抗生物質 } \\
\text { 無添加区 }\end{array}$} & (1) & 93 & $10.8(10)$ & $10^{6}$ & 0.0 & $(0)$ & $10^{6}$ \\
\hline & (2) & 81 & $25.9(21)$ & $10^{3}$ & 1.2 & $(1)$ & $10^{4}$ \\
\hline & (3) & 72 & 25.0 & $10^{3}$ & 2.8 & $(2)$ & $10^{4}$ \\
\hline & (4) & 90 & $27.8(25)$ & $10^{2}$ & 0.0 & $(0)$ & $10^{3}$ \\
\hline & 計 & 336 & $22.0(74)^{b}$ & & 0.9 & $(3)^{b}$ & \\
\hline
\end{tabular}

a,b 同列間の異符号間に有意差あり $\quad(\mathrm{P}<0.01)$

* $\mathrm{CFU} \quad \mathrm{ml}$

** 菌分離陰性 


\section{卵割率および胚発生率}

$\mathrm{PC}+\mathrm{SM}$ 添加区および無添加区における体外受精胚 の卵割率は，それぞれ $41.4 \sim 51.6 \%$ (平均 $46.7 \%$ )， $10.8 \sim 27.8 \%$ (平均 $22.0 \%$ ) で，胚盤胞発生率はそれぞ れ $6.1 \sim 14.1 \%$ (平均 $9.8 \%$ )， $0 \sim 2.8 \%$ (平均 $0.9 \%$ ) と $\mathrm{PC}+\mathrm{SM}$ 添加区が無添加区に比べ有意に高い值 $(\mathrm{P}<$ 0.01）を示した（表 3$)$.

\section{考察}

本研究では，抗生物質を添加した卵巣輸送液および卵 巣洗浄液から, $10^{1} \sim 10^{3} \mathrm{CFU} / \mathrm{ml}$ の細菌が分離された。 これは，卵巣採取が内臓検査台で行われるため卵巣への 細菌污染の機会が多く, 洗浄操作によっても卵巣に付着 した細菌を除去することができなかったものと思われ る. 洗浄液の肉眼的な観察に拈いて, 洗浄の回数が進む に従い, 透明度が増してくるが, 細菌数としては有意な 差は認められなかった。音井ら［7］は，細菌暴露した 未成熟卵子を，抗生物質無添加の洗浄液で 10 回洗浄し ても細菌が除去できないことを報告した。本研究におい ても同様に抗生物質無添加区においては，卵巣輸送液か ら発生培養液までの全供試材料から，10 $\sim 10^{6} \mathrm{CFU} / \mathrm{ml}$ の細菌が分離されたが，PC+SM添加区においては， 卵子吸引液以降の培養液から細菌が分離されなかった。 また, 卵巣輸送液や卵巣洗浄液に抗生物質を加えること により，約 $1 / 10$ 以下に細菌数が減少したこと，抗生 物質を加えた洗浄液にも細菌が検出されるが，卵子吸引 液，成熟培養液には抗生物質を加えることによって細菌 が見られなくなることから，体外受精胚作出過程におけ る抗生物質の添加は不可欠のものであることが示唆され た。一方, 卵巣輸送液は, 多種類の細菌によって污染さ れており，それらの細菌にはPCとSMに対して感受性 の低い細菌が存在することが示唆された. 卵巣輸送後, 滅菌生理食塩液で卵巣を 5 回洗浄することにより, 細菌 の数および種類は減少したが，卵巣の洗浄が不十分であ ると, 卵子回収液まで多くの細菌によって污染される危 険性があることが示唆された。

このことから，抗菌スペクトルの広い抗生物質の洗浄 液および培養液への添加が必須であると考えられた。

牛の体内受精胚において, Haemophilus somnus, Brucella abortus との共培養により胚の生存性が低下したと いう報告 $[3,8]$ がある. 本研究においても，胚の発 生過程での細菌污染により，体外受精胚の卵割率，胚盤 胞への発生率を有意に低下することが示された。この発 育能の低下は, 培養液の肉眼的な観察においても, 黄
変・混濁や赤変を伴ったことから, 培養液中での細菌増 殖による培養液の $\mathrm{pH}$ の変動および細菌が産出する毒素 によるものと推察された $[8]$. 一方, 音井ら [7]は 体外受精胚の卵割率，胚盤胞への発生率を損なわないた めには牛体外受精胚作出過程において有効な抗生物質の 添加が必要であることを示唆している。また, Stringfellow ら [9-11] は, 透明帯が正常な牛の体内受精胚を, 抗生物質の含まない洗浄液で繰り返し洗浄することによ り，付着したBrucella abortusを除去できるが，透明带 の欠損胚では洗浄による除去が困難であることを指摘し ている. Thomsonや Riddell ら [8,12］は、洗浄液に抗生 物質を添加することにより Haemophilus somnusを除去 できるがMycoplasmaは除去できないことを指摘してい る. 加えて, 本研究で分離された細菌のうち Salmonella は, 人畜の感染症として注意を要する細菌であり, 高率 な薬剤耐性化，多剂耐性化が指摘されている [13]。

これらのことから，体外受精胚生産過程での細菌污染 は，胚発生率の低下だけでなく，胚の移植による受胎率 の低下を誘起する可能性があることから, 卵巣の採取方 法の改善および輸送液中の細菌増殖抑制に有効な抗生剂 の添加が重要であると思われた。

\section{謝 辞}

卵巣採材にご協力いただいた北九州市立食肉センター の皆様とご校閲を賜った山口大学鈴木達行教授に感謝の 意を表します。

\section{引用文献}

1. Del Campo MR, Tamayo R, Del Campo CH. A serologic study of the progeny of a Brucella abortus seropositive cow. Theriogenology 1989;31:1249-1251.

2. Rohde RF, Shulaw WP, Hueston WD, Bech-Nielsen S, Haibel GK, Hoffsis GF. Isolation of Mycobacterium paratuberculosis from washed bovine ova after in vitro exposure. Am J Vet Res 1990; 51: 708-710.

3. Singh EL. The disease control potential of embryos. Theriogenology 1987; 27: 9-20.

4. Stringfellow DA, Lauerman LH, Nasti KB, Galik PK. Trypsin treatment of bovine embryos after in vitro exposure to infectious bovine rhinotracheitis virus or bovine herpesvirus-4. Theriogenology 1990; 34: 427-434.

5. 梶原 豊, 後藤和文, 小坂昭三, 中西喜彦, 小川清彦. 牛 卵胞卵子の体外受精㧍よび体外培養によるふ化，家畜繁殖 雑誌 1987; 33: 173-180.

6. Cowan ST. 医学細菌同定の手びき。(井崎利一訳) 東京： 近代出版；1974.

7. 音井威重, 立川 進, 近藤正治, 鈴木達行. 牛における未 成熟卵子の細菌暴露が体外発生能に及ぼす影響. J Reprod Devel 1992; 38: j61-j66. 
8. Thomson MS, Stringfellow DA, Lauerman LH. Adherence of Haemophilus somnus to bovine embryos after in vitro exposure. Am J Vet Res 1988; 49: 63-66.

9. Stringfellow DA, Howell VL, Schnurrenberger PR. Investigation into the potential for embryo transfer from Brucella abortus infected cows without transmission of infection (a,b,c). Theriogenology 1982; 18: 733-743.

10. Stringfellow DA, Wolfe DF, Lauerman LH, Sparling PH. Resistance of preimplantation bovine embryos to infection with Brucella abortus. Am J Vet Res 1986; 47: 1924-1927.
11. Stringfellow DA, Scanlan CM, Brown RR, Meadows GB, Gray BW, Young-White RR. Culture of bovine embryos after in vitro exposure to Brucella abortus $(\mathrm{a}, \mathrm{b}, \mathrm{c})$. Theriogenology 1984; 21: 1005-1012.

12. Riddell KP, Stringfellow DA, Panangala VS. Interaction of Mycoplasma bovis and Mycoplasma bovigenitalium with preimplantation bovine embryos. Theriogenology 1989; 32: 633-641.

13. 中野達郎, 浜岡隆文, 寺門誠致. 牛の病性鑑定材料由来开 ルモネラの薬剂耐性. 日獣会誌 1988; 41: 806-808.

\title{
Isolation of Bacteria from In Vitro Bovine Embryo Production System and Effect of Bacterial Contamination on the Developmental Capacity of In Vitro Fertilized Embryo
}

\author{
Yukinori Uchinuno, Kazuaki Masuoka", Shozo Tsutsumi", Toshihiro Komori", \\ Takeshige Отог ${ }^{2}$ \\ Fukuoka Prefectural Tyuo Livestock Hygiene Service Center, Hakata, Fukuoka 816, \\ ${ }^{1)}$ Fukuoka Prefectural Kitakyushu Livestock Hygiene Service Center, Kitakyushu, Fukuoka \\ 800-02, ${ }^{2)}$ Tokushima Prefectural Beef Cattle and Swine Experiment Station, Anan, Tokushima 774.
}

Summary. The objectives of this study were to isolate bacteria from in vitro fertilized (IVF) bovine embryo product system with or without antibiotics (penicillin + streptomycin) and to determine whether bacterial contamination affected the development of IVF embryos. $10^{1}$ to $10^{3}$ colony forming units (CFU) $/ \mathrm{ml}$ of bacteria were isolated from transport medium and wash medium with antibiotics of slaughterhouse derived ovaries, but no bacteria were recovered from subsequent wash medium of oocytes and in vitro culture medium. In contrast, $10^{1}$ to $10^{6} \mathrm{CFU} / \mathrm{ml}$ of bacteria were isolated from all media without antibiotics used in IVF embryo product system. The bacteria isolated from transport medium were mainly gram negative rods and resistant to antibiotics of penicillin, macrolide, tetracyclin and cephem line. The rates of cleavage and development to blastocysts of IVF embryos produced in IVF embryo product system with antibiotics were significantly higher than without antibiotics. It was concluded that effective antibiotics should be added to IVF bovine embryo product system for removing or killing bacteria adhered to ovaries, oocytes or embryos. 